\title{
Cripto-1 induces apoptosis in HC-11 mouse mammary epithelial cells
}

\author{
ML De Santis ${ }^{2}$, I Martinez-Lacaci ${ }^{1}$, C Bianco ${ }^{1}$, M Seno ${ }^{3}$, \\ B Wallace-Jones ${ }^{1}$, N Kim ${ }^{1}$, A Ebert ${ }^{4}$, C Wechselberger ${ }^{1}$ \\ and DS Salomon ${ }^{\star, 4}$ \\ 1 Tumor Growth Factor Section, Laboratory of Tumor Immunology and Biology, \\ $\mathrm{NCl}$, National Institute of Health, Bethesda, Maryland 20892, USA \\ 2 Department of Molecular Pathology, Walter Reed Army Institute of Research, \\ Washington DC 20307, USA \\ 3 Department of Bioscience and Biotechnology, Faculty of Engineering, \\ Okayama University, Okayama 700-8530, Japan \\ ${ }^{4}$ Depts. of Obstetrics and Gynecology, Free University of Berlin, Berlin, Germany \\ * Corresponding author: DS Salomon, Building 10, Room 5B39, Tumor Growth \\ Factor Section, Laboratory of Tumor Immunology and Biology, NCI, National \\ Institutes of Health, Bethesda, MD 20892, USA. Tel: 301-496-9536; Fax: 301- \\ 402-8656; E-mail: davetgfa@helix.nih.gov
}

Received 15.4.99; revised 11.8.99; accepted 23.8.99

Edited by $\mathrm{C}$ Thiele

\begin{abstract}
Cripto-1 (CR-1) is an epidermal growth factor (EGF)-related protein. CR-1 can inhibit $\beta$-casein and whey acidic protein expression in mouse mammary epithelial cells. The present study demonstrates that CR-1 can induce apoptosis in HC-11 mouse mammary epithelial cells, as measured by bisbenzimide stained nuclei, TUNEL assay and cell death ELISA. Apoptosis could be observed after 2 days of exposure of confluent HC-11 cells to CR-1 in the absence of the survival factors EGF and insulin, with maximum apoptosis occurring at 3 days. A reduction in poly(ADP-ribose) polymerase (PARP) expression and an increase in $\beta$-catenin cleavage was found after $18 \mathrm{~h}$ of exposure to CR-1 suggesting that apoptosis was preceded by the induction of a caspase activity since the caspase inhibitor ZFAD.FMK could block the CR-1-induced reduction in PARP expression and CR-1-induced apoptosis. CR-1 was found to increase the expression of caspase-3-like protease. Although, the levels of p27 ${ }^{\mathrm{kip} 1}$ and p21Bax did not change after exposure to CR-1 for $18 \mathrm{~h}$, the levels of $\mathrm{BCl}-\mathrm{x}_{\mathrm{L}}$ became undetectable. These studies suggest that CR-1 promotes apoptosis by mediating the induction of caspase3-like protease and downregulating the expression of $\mathrm{Bcl}-\mathrm{x}_{\mathrm{L}}$. Cell Death and Differentiation (2000) 7, 189-196.
\end{abstract}

Keywords: apoptosis; Cripto-1; caspase activation; mammary epithelial cells

Abbreviations: CR-1, cripto-1; EGF, epidermal growth factor; PARP, poly(ADP-ribose) polymerase; Z-VAD.FMK, benzyloxycarbonyl-Val-Ala-Asp (Ome) fluoromethyl ketone; BOC, BocAsp(Ome) fluoromethyl ketone

\section{Introduction}

During normal mammary gland development, programmed cell death (PCD) and cell proliferation play a major role in controlling tissue remodeling and growth. ${ }^{1}$ Processes such as ductal morphogenesis, lobulo-alveolar development during pregnancy and lactation and involution are characterized by different degrees of apoptosis and proliferation. ${ }^{2,3}$ These biological mechanisms are controlled by an interplay of hormones, growth factors, cell-cell and cell-matrix interactions. ${ }^{4}$ One of the locally-derived growth factor families that has been implicated in these processes is the epidermal growth factor (EGF) family., ${ }^{1,5}$ Both EGF and transforming growth factor- $\alpha$ (TGF- $\alpha$ ) can stimulate the proliferation of mammary epithelial cells and lobulo-alveolar development in the mammary gland of virgin mice. ${ }^{1,6}$ These growth factors are also able to modulate milk protein expression in mammary epithelial cells when cells are exposed to lactogenic hormones $^{7}$ and can inhibit apoptosis in secretory alveolar epithelial cells in the involuting mammary gland when ectopically overexpressed. ${ }^{8}$

We recently identified another EGF-related protein, CR-1 (cripto-1) that can also modulate mammary epithelial cell morphogenesis and differentiation..$^{7,9-12}$ CR-1 is a member of a larger family of structurally related proteins, the EGFCFC family that also includes, mouse $\mathrm{Cr}-1$, mouse cryptic, Xenopus FRL-1 and zebrafish oep. ${ }^{7}$ These proteins perform an essential function during early vertebrate embryogenesis by promoting the formation of mesoderm during gastrulation and by facilitating the initial migration of epiblast cells from the primitive streak. Human CR-1 is a 28-kD glycoprotein cotaining 188 amino acids. CR-1 contains three intra-disulfide bonds encompassing a modified EGF-like consensus sequence of approximately 37 amino acids. However, unlike other EGF-like proteins, the human CR-1 protein lacks a conventional hydrophobic signal peptide and transmembrane domain and the modified EGF-like motif which is also possessed by other members of the EGF-CFC family, lacks the A loop, while the $B$ loop is truncated. ${ }^{13}$ Another feature that distinguishes CR-1 from other EGF-like peptides is the failure of CR-1 to directly bind to any of the known c-erb-B type 1 receptor tyrosine kinases. ${ }^{13}$ However, CR-1 can indirectly induce a transient increase in the tyrosine transphosphorylation of $\mathrm{C}$ erb-B 4 in mouse and human mammary epithelial cells. ${ }^{14}$ CR-1 can inhibit $\beta$-casein and whey acidic protein (WAP) expression in vitro in mouse mammary epithelial cells. ${ }^{9,11,12}$ CR-1 can also induce in vitro and in vivo branching morphogenesis in mouse mammary epithelial cells. ${ }^{7,10,11}$ $\mathrm{Cr}-1$ is normally expressed at a low level in a subpopulation of mammary epithelial cells within the growing terminal end buds of the virgin mouse mammary gland. ${ }^{15,16}$ However, $\mathrm{Cr}-1$ expression in ductal epithelial cells increases during pregnancy, lactation and also in the aged mouse mammary 
gland. ${ }^{10,12,15,16}$ CR-1 mRNA and immunoreactive CR-1 protein are expressed in several human breast cancer cell lines, in approximately $80 \%$ of primary human breast carcinomas and in several different types of spontaneous and transgenic mouse mammary tumors. ${ }^{17-20}$ With respect to intracellular signaling, CR-1 is able to activate the ras/raf/ MEK/MAPK and the PI3-kinase signaling pathways. ${ }^{9,11,13}$ In this regard, the activation of $\mathrm{p} 21^{\text {ras }}$ and PI3-kinase has been linked to the ability of CR-1 to inhibit the expression of $\beta$-casein and WAP in mouse mammary $\mathrm{HC} 11$ epithelial cells and in primary cultures of midpregnant mouse mammary epithelial cells. ${ }^{9}$

The present study was designed to ascertain if CR-1 might modulate apoptosis in $\mathrm{HC}-11$ mouse mammary epithelial cells under conditions where $\beta$-casein expression is inhibited. CR-1 was found to induce apoptosis in serumrestricted confluent cultures of $\mathrm{HC}-11$ cells through a caspase-dependent process since several proteins that are substrates for caspases such as poly(ADP-ribose) polymerase (PARP) and $\beta$-catenin ${ }^{21-23}$ were found to degraded after CR-1 treatment. In addition, we have found that CR-1 decreases the expression of bcl- $x_{L}$ but not $p 21$ bax or p2 $7^{\text {kip1 }}$ expression. ${ }^{24,25}$

\section{Results}

\section{CR-1 inhibits HC-11 mammary epithelial cell growth under serum-restricted conditions}

Compared to EGF, CR-1 is a relatively weak mitogen in vitro for human and mouse mammary epithelial cells.9,12,26 To ascertain if CR-1 might modulate mammary epithelial cell apoptosis, we used $\mathrm{HC}-11$ mouse mammary epithelial cells, a clone derived from the mouse mammary epithelial COMMA-D cell line. ${ }^{27}$ It has previously been reported that confluent $\mathrm{HC}$ 11 cells undergo apoptosis under serum-free medium conditions in the absence of the survival factors, EGF or insulin. $^{28}$ Therefore, proliferation of $\mathrm{HC}-11$ cells in sparse cultures in response to $\mathrm{CR}-1$ was assessed in $3 \% \mathrm{FBS}$ containing medium (Figure 1). After $48 \mathrm{~h}$ or $72 \mathrm{~h}$ of exposure to different concentrations of CR-1, HC-11 cell growth was reduced by nearly $70 \%$ after $72 \mathrm{~h}$ with $2.5 \mathrm{ng} / \mathrm{ml}$ as compared to control cultures (no CR-1 added) (Figure 1).

\section{CR-1 promotes apoptosis in HC-11 mammary epithelial cells}

To ascertain if the growth inhibitory effects of CR-1 in low serum might be associated with any effect CR-1 might have on apoptosis, confluent $\mathrm{HC}-11$ cells that were depleted of EGF or insulin, were exposed for either $1-5$ days to CR-1 $(100 \mathrm{ng} / \mathrm{ml})$ in low serum and in the absence of EGF or insulin. These conditions were selected since there is an increase in the response of $\mathrm{HC}-11$ cells to apoptosis at confluency as compared to sparse subconfluent cells with respect to growth factor withdrawal. ${ }^{42}$ After 2 days of exposure to CR-1 (100 ng/ $\mathrm{ml}$ ), a significant number of confluent $\mathrm{HC}-11$ cells exhibited detectable signs of apoptosis, namely, nuclear fragmentation and the appearance of apoptotic bodies (Figure 2, Table 1). These effects were maximum after a 3 day exposure.

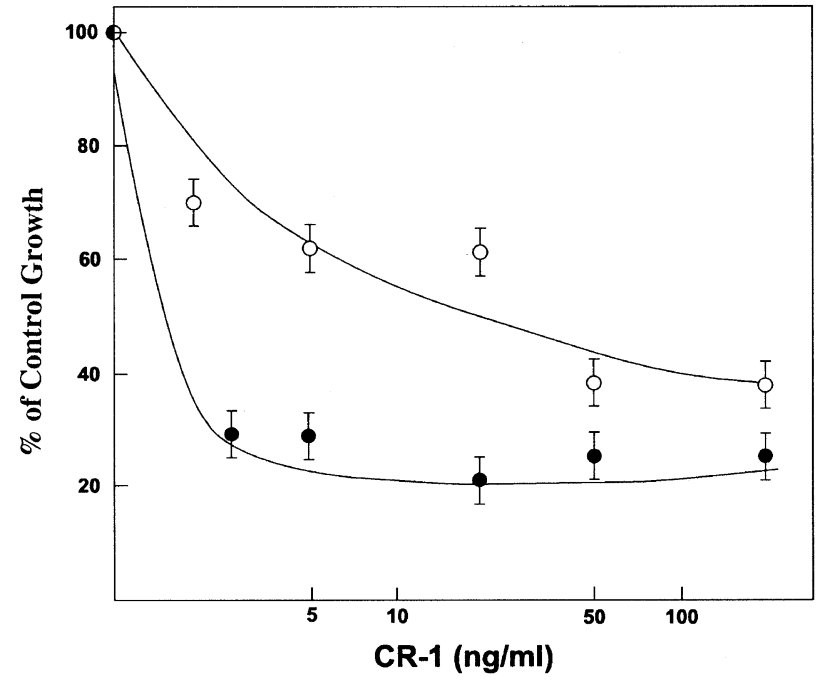

Figure 1 CR-1 inhibits mammary epithelial cell growth. HC-11 cells were seeded at $2 \times 10^{3}$ cells/well in a 96 well-tissue culture plate in RPMI 1640 medium containing $3 \%$ Fetal Bovine Serum (FBS). The cultures were treated with increasing concentrations of CR-1 for $48(\mathrm{O})$ and $72 \mathrm{~h}(\mathbf{O})$. The cells were incubated with tetrazolium salt (WST-1) for $4 \mathrm{~h}$ and the formed formazan dye was quantitated using an ELISA reader
3 days

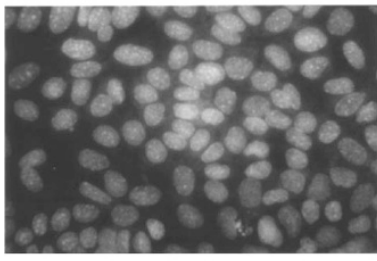

CONTROL

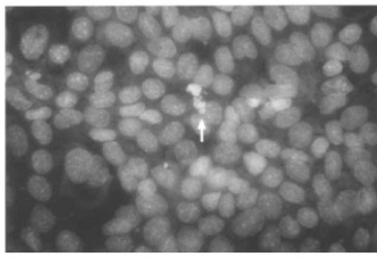

EGF

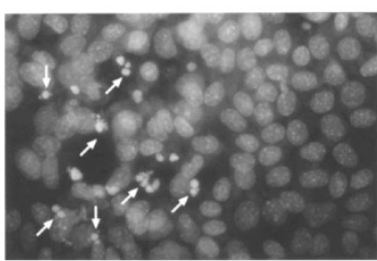

CR-1
5 days

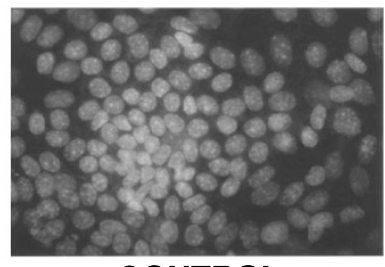

CONTROL

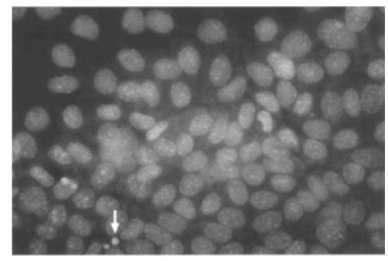

EGF

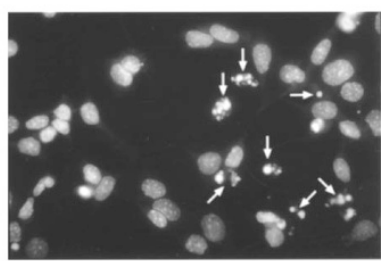

CR-1
Figure 2 CR-1 induces apoptosis in $\mathrm{HC}-11$ cells. $\mathrm{HC}-11$ cells were grown to confluency and then maintained in $3 \%$ FBS containing medium with or without CR-1 $(100 \mathrm{ng} / \mathrm{ml})$ or EGF $(100 \mathrm{ng} / \mathrm{ml})$ for 3 and 5 days. Cell nuclei were stained with bisbenzimide (Hoechst 33258) and apoptosis was assessed by nuclear morphology. Evidence of apoptosis is indicated by the white arrows, i.e., contraction of the cell body, condensation of nuclear chromatin and fragmentation, and the production of apoptotic bodies 
Approximately $17-19 \%$ of the $\mathrm{HC}-11$ cells were apoptotic in CR-1-treated HC-11 cells as ascertained by bis-benzimide staining in the majority of the fields that were analyzed (Figure 2, Table 1). These findings were confirmed using two additional apoptosis assays on confluent HC-11 cells, the TUNEL assay (Figure 3) and the cell death ELISA (Figure 5).

Table 1 Quantification of apoptosis mediated by CR-1

$\%$ apoptotic cells

\begin{tabular}{lcr}
$\begin{array}{l}\text { Days in the } \\
\text { presence of CR-1 }\end{array}$ & Control & CR-1 \\
\hline 1 & 1.34 & 0.9 \\
2 & 0.65 & 13.9 \\
3 & 1.3 & 16.6 \\
4 & 2.1 & 16.7 \\
5 & 2.4 & 19.8 \\
\hline
\end{tabular}

Cell nuclei were stained with bisbenzimide (Hoechst 33258) and apoptosis was assessed by nuclear morphology. CR-1 was used at $100 \mathrm{ng} / \mathrm{ml}$. Three random fields per exposure were analyzed. The number of experiments performed independently were two per each condition

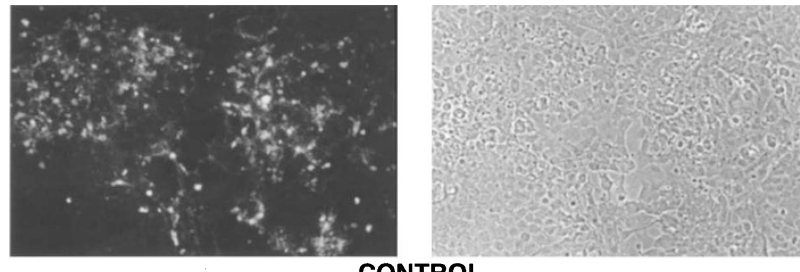

CONTROL

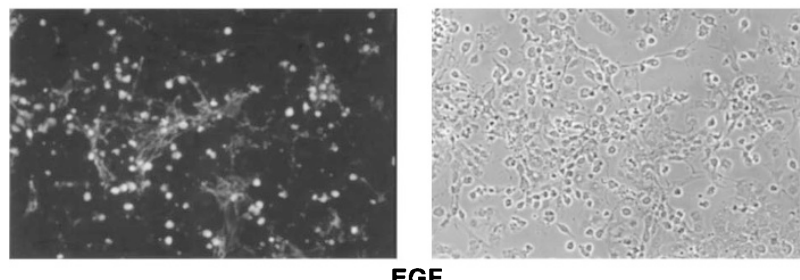

EGF
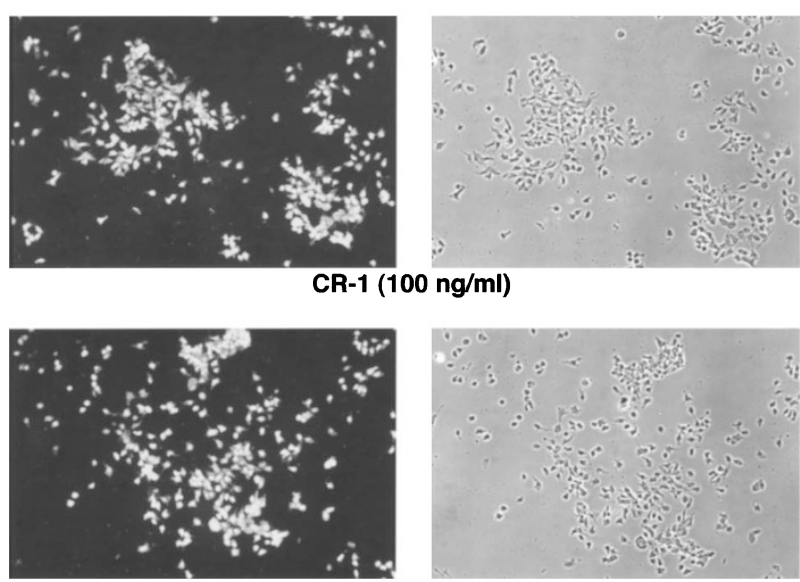

CR-1 (200 ng/ml)

Figure 3 CR-1 induced-apoptosis as assessed by TUNEL assay. HC-11 mammary epithelial cells were grown to confluency and then maintained in $3 \%$ FBS containing medium with or without CR-1 (100 or $200 \mathrm{ng} / \mathrm{ml}$ ) or EGF $(100 \mathrm{ng} / \mathrm{ml})$ for 5 days
Figure 3 shows that the majority of CR- 1 treated $\mathrm{HC}-11$ cells were positive in the TUNEL assay. After 5 days of exposure, the amount of $\mathrm{HC}-11$ cells undergoing apoptosis in response to CR-1 was dramatically higher when compared to the control cell cultures (Table 1). In addition, CR-1 was able to promote apoptosis as assessed by Hoechst staining in $\mathrm{HC}-11$ cells in a dose-dependent manner (Figure 4). After 5 days of exposure to CR-1, HC-11 cells showed significant apoptotic features even when they were exposed to $2.5 \mathrm{ng} / \mathrm{ml}$.

\section{CR-1 induces caspase-mediated apoptosis in HC-11 mammary epithelial cells}

To further define the biochemical processes that might be involved in the CR-1-mediated apoptotic effect on $\mathrm{HC}-11$ cells, caspase activation was studied since caspase induction and / or activation is an important feature of the apoptotic signaling pathway that normally precedes nuclear fragmentation. ${ }^{22}$ By using a cell death ELISA, DNA fragmentation and therefore an index of apoptosis could be quantified in confluent $\mathrm{HC}-11$ cells that had been exposed to $100 \mathrm{ng} / \mathrm{ml}$ of CR-1 in the absence of EGF or insulin (Figure 5). In order to establish the involvement of caspases in this process, a general caspase inhibitor BOC $(10 \mu \mathrm{M})$ was used. As shown in Figure 5, the caspase inhibitor was able to completely abolish CR-1-mediated apoptosis. A comparable inhibitory effect was also observed when $20 \mu \mathrm{M}$ ZVAD.FMK caspase inhibitor was used, suggesting that CR-1 may activate the caspase- 3 subfamily of proteases and then induce apoptosis. $^{29}$

\section{CR-1-mediated caspase activation is associated with decreased PARP expression and $\beta$-catenin cleavage in $\mathrm{HC}-11$ cells}

Poly(ADP-ribose) polymerase (PARP) is one of the main substrates for caspases. ${ }^{30}$ Therefore, the steady state levels

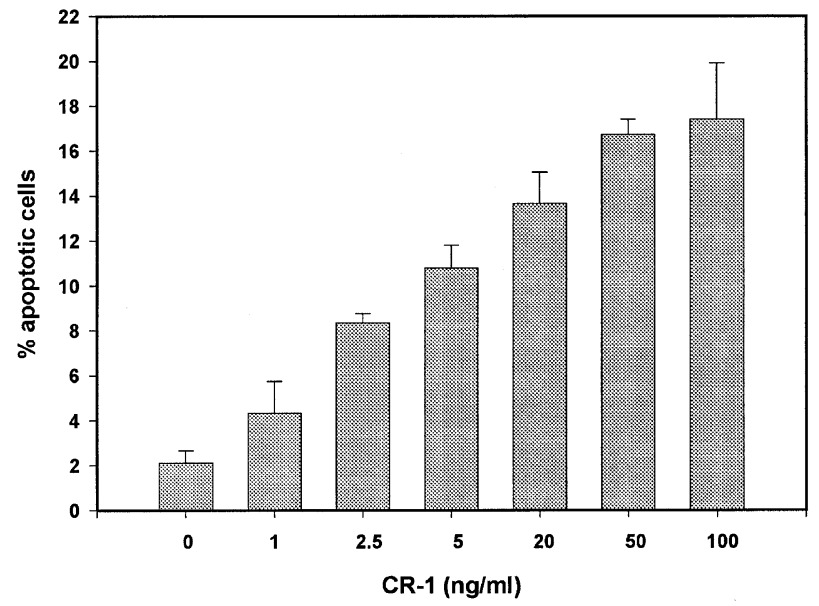

Figure 4 CR-1 induces apoptosis in HC-11 cells in a dose-dependent manner. Apoptosis was assessed by nuclear morphology using bisbenzimide (Hoechst 33258) staining in confluent $\mathrm{HC}-11$ cells mantained in 3\% FBS containing medium after 5 days of CR-1 exposure. Results are expressed as the mean \pm S.E. 
of intact PARP protein expression were assessed by Western blot analysis in lysates from confluent $\mathrm{HC}-11$ cells that had been exposed to CR-1. CR-1 (100 ng/ml) was able to induce a significant reduction in the levels of intact p116 PARP protein following an $18 \mathrm{~h}$ treatment (Figure 6). No evidence of a decrease in PARP levels was found at $10 \mathrm{~h}$ or $12 \mathrm{~h}$ after exposure to CR-1 (data not shown). The reduction in PARP levels in response to CR-1 was partially blocked with the general caspase inhibitor BOC and completely with $20 \mu \mathrm{M}$ of the caspase-3 inhibitor ZVAD.FMK, suggesting that the

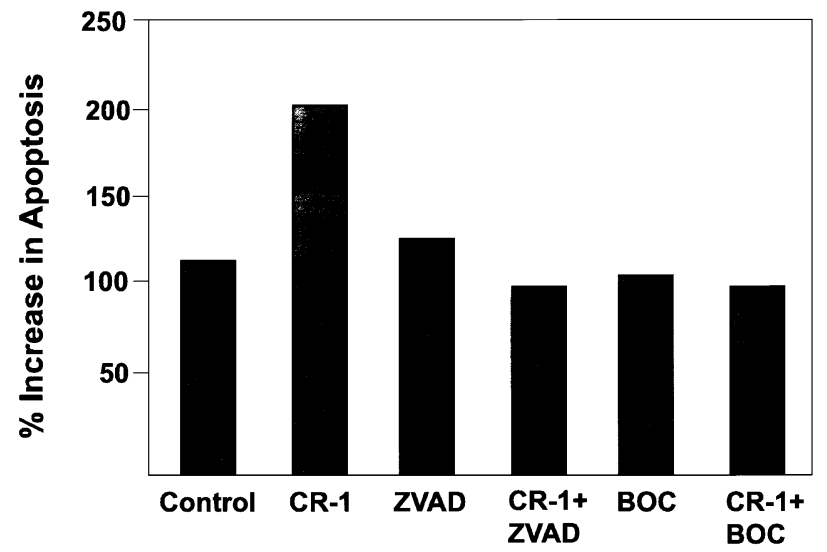

Figure 5 Inhibition of CR-1-mediated apoptosis by caspases inhibitors Apoptosis was quantitated by detecting apoptotic DNA fragments in lysates using histone-DNA ELISA. HC-11 cells were grown until confluency and exposed to CR-1 (100 ng/ml) with or without inhibitors for $36 \mathrm{~h}$. ZVAD.FMK caspase inhibitor (ZVAD) was used at $20 \mu \mathrm{M}$ and the general caspase inhibitor BMD.FMK (BOC) was used at $10 \mu \mathrm{M}$. The cells were preincubated for $1 \mathrm{~h}$ with the caspase inhibitors prior to the addition of the growth factors. The results are expressed as the mean of two separate experiments

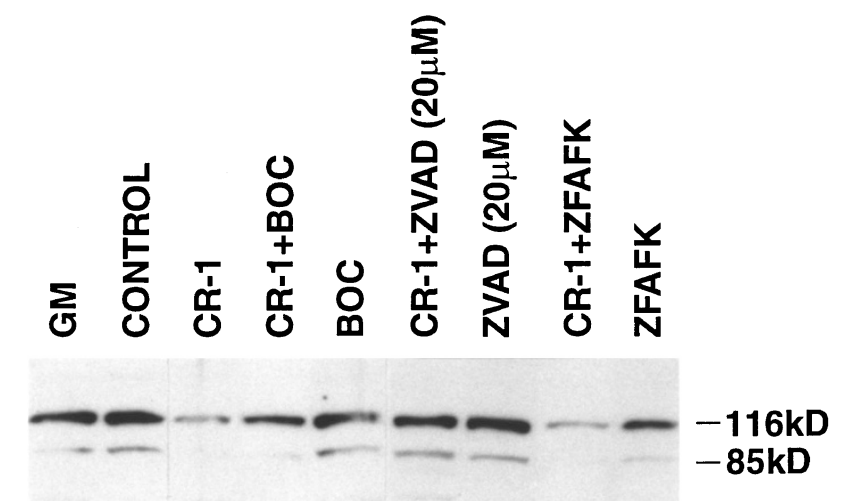

Figure 6 CR-1 reduces PARP expression. HC-11 cells were grown until confluency and treated with CR-1 $(100 \mathrm{ng} / \mathrm{ml})$ with or without caspase inhibitors for $18 \mathrm{~h}$. The cells were preincubated for $1 \mathrm{~h}$ with the caspase inhibitors prior to the addition of CR-1. ZVAD.FMK caspase inhibitor (ZVAD) was used at $20 \mu \mathrm{M}$, BMD.FMK general caspase inhibitor (BOC) was used at $10 \mu \mathrm{M}$ and ZFAFK.FMK, caspase inhibitor negative control, was used at $20 \mu \mathrm{M}$. The results of one experiment which is representative of three, are shown. PARP protein expression was determined by Western blot analysis of treated HC-11 cell lysates using anti-PARP antibodies. The intact full length PARP protein $(116-\mathrm{kD})$ and the $85-\mathrm{kD}$ fragment are denoted by an arrow respectively reduction in PARP levels might be due to the activation of a caspase-3-like protease. When $20 \mu \mathrm{M}$ of the inactive caspase inhibitor, ZAFAFK.FMK was added to HC-11 cells, CR-1 was still able to induce a reduction in PARP levels (Figure 6).

To more fully define the involvement of caspase-3-like activation in CR-1-mediated apoptosis, the levels of $\beta$ catenin, a caspase-3 substrate, were analyzed in $\mathrm{HC}-11$ cells. ${ }^{21}$ As shown in Figure 7, CR-1 at either 10 or $100 \mathrm{ng} /$ $\mathrm{ml}$ induced the cleavage of the $92 \mathrm{kD} \beta$-catenin protein to a $\sim 90 \mathrm{kD}$ fragment in confluent $\mathrm{HC}-11$ cells after an $18 \mathrm{~h}$ incubation period. The appearance of this intermediate $\sim 90 \mathrm{kD} \beta$-catenin degradation fragment has been previously reported. ${ }^{21}$ In contrast to $\beta$-catenin, the levels of $\alpha$ catenin were not significantly altered in confluent $\mathrm{HC}-11$ cells after exposure to CR-1. In order to correlate this caspase activity with the presence of the caspase- 3 precursor protein, CPP32, the levels of CPP32 protein expression were measured in $\mathrm{HC}-11$ cells by Western blot analysis. The levels of CPP32 protein were extremely low in control untreated $\mathrm{HC}-11$ cells or in cells treated with $10 \mathrm{ng} / \mathrm{ml}$ of CR-1. In contrast, a threefold increase in CPP32 expression was observed in $\mathrm{HC}-11$ cells that had been treated with CR-1 (Figure 7).

\section{Effect of CR-1 on the expression of apoptotic associated proteins in $\mathrm{HC}-11$ cells}

To ascertain if CR-1 might affect the expression of several key pro- or anti- apoptotic proteins, the levels of bcl- $x_{\mathrm{L}}, \mathrm{p} 27^{\mathrm{kip} 1}$ and p21 bax were studied. ${ }^{31,32}$ The anti-apoptotic protein, bcl- $x_{\mathrm{L}}$, was found to be expressed in confluent $\mathrm{HC}-11$ mammary epithelial cells (Figure 8). However no bcl- $x_{L}$ expression was found in confluent HC-11 after exposure to CR-1 (Figure 8). The levels of $\mathrm{p} 27^{\mathrm{kip} 1}$, a negative regulator of the cell cycle, did not change in response to CR-1 exposure. With respect to the pro-apoptotic protein p21 bax, the levels of this protein remained unchanged after CR-1 treatment of $\mathrm{HC}-11$ cells (Figure 8).

\section{Discussion}

Growth and differentiation in the mammary gland are regulated by a coordinated interplay of systemic mammotrophic hormones and locally-derived growth factors. ${ }^{1,33}$ The complexity of the biological roles of these factors is not completely understood. In an attempt to more fully elucidate the potential role that a novel growth factor and morphogen CR-1 might perform in mammary epithelial cells, we have studied the effects of CR-1 on the differentiation of a normal mammary epithelial cell line, $\mathrm{HC}-11$. $\mathrm{HC}-11$ cells resemble midpregnant mammary epithelial cells in that they express the milk protein, $\beta$-casein in response to lactogenic hormone stimulation. ${ }^{28}$ CR-1 can inhibit the expression of the milk protein, $\beta$-casein, in $\mathrm{HC}-11$ cells when these cells are simultaneously exposed to lactogenic hormones at confluency. ${ }^{9}$ This may be physiologically significant in vivo since elevated expression of mouse $\mathrm{Cr}-1$ occurs in the pregnant and lactating mouse mammary gland. ${ }^{12,15}$ In this report we have identified another role of CR-1, namely, its ability to promote apoptosis in confluent, survival-factor-depleted HC- 
11 mammary epithelial cells. This effect is preceded by the activation of a caspase-3-like protease(s). This conclusion is based on several observations. First, the ZVAD.FMK caspase inhibitor can block CR-1-induced apoptosis in $\mathrm{HC}-11$ cells
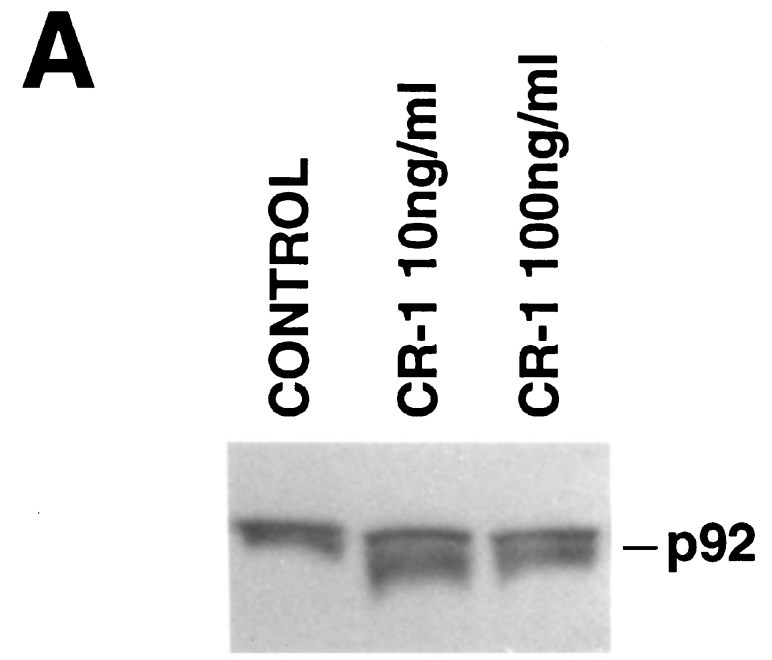

WB: $\beta$-catenin

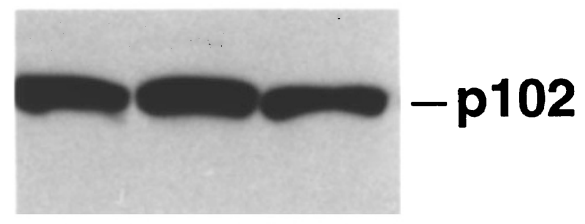

WB: $\alpha$-catenin

B

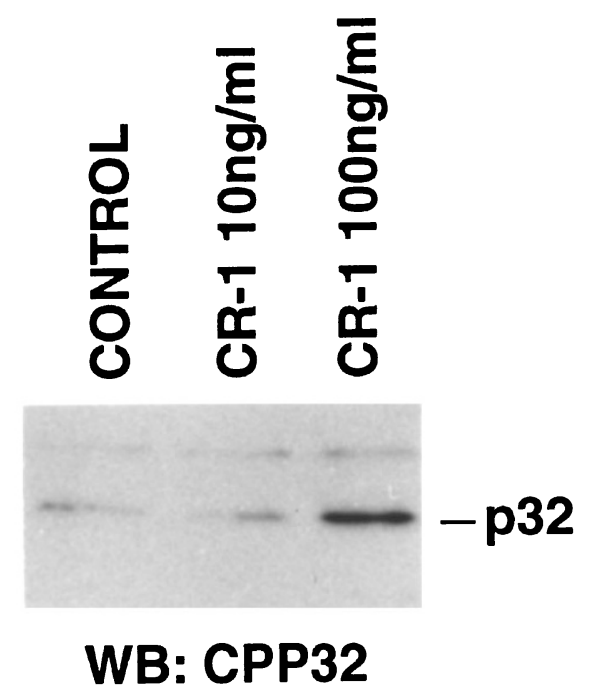

Figure $7 \quad \beta$-catenin, $\alpha$-catenin and CPP32 protein expression in $\mathrm{HC}$ - 11 cells exposed to CR-1 $(100 \mathrm{ng} / \mathrm{ml})$ in RPMI 1640 medium containing 3\% FBS for $18 \mathrm{~h}$. Western blot analyses using anti- $\beta$ catenin, anti- $\alpha$-catenin or antiCPP32 antibodies were performed as described in Materials and Methods
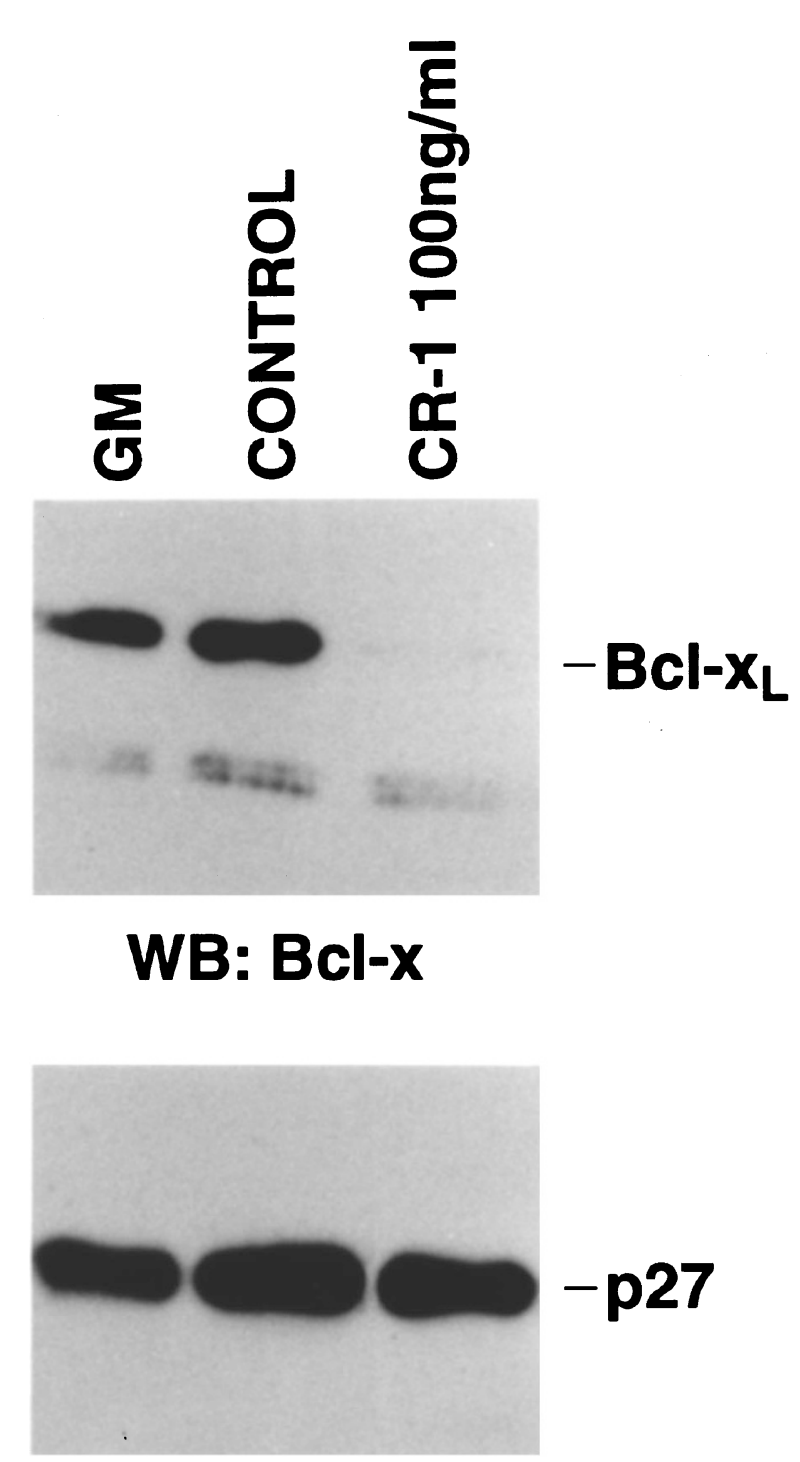

WB: p27

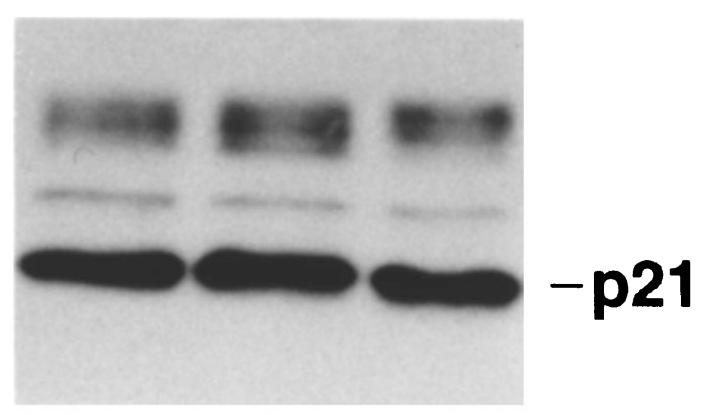

\section{WB: Bax}

Figure $8 \mathrm{Bcl}-\mathrm{x}, \mathrm{p} 27^{\mathrm{kip} 1}$ and $\mathrm{p} 21 \mathrm{Bax}$ protein expression in mammary epithelial HC-11 cells treated with CR-1 $(100 \mathrm{ng} / \mathrm{ml})$ in RPMl 1640 medium containing $3 \%$ FBS; or GM (10\% FBS containing medium) for $18 \mathrm{~h}$. Western blot analyses using anti-Bcl-x, anti-p2 $7^{\mathrm{kip} 1}$ and anti-p21 Bax antibodies were performed as described in Materials and Methods 
when used at concentrations that are sufficient to inhibit caspase-3 activation. ${ }^{29}$

Second, substrates for caspase-3 like proteases such as PARP and $\beta$-catenin were found to be either reduced or cleaved in CR-1 treated HC-11 mammary epithelial cells, respectively. Finally, CR-1 downregulated the expression of the anti-apoptotic protein, bcl- $x_{\mathrm{L}}$, without affecting the expression of p21 bax. This effect is distinct from the survival promoting effects of EGF which upregulate the expression of $b c l-x_{L}$ in mammary epithelial cells. ${ }^{50}$ These findings support the possibility that CR-1 may be activating a caspase-3-like protease, since it has been reported that bcl- $\mathrm{x}_{\mathrm{L}}$ can be cleaved in vitro by activated caspase-3. ${ }^{34}$ Human mammary epithelial cells generally show low or undetectable levels of CPP32, the precursor protein of caspase-3 as compared to human breast cancer cells. ${ }^{35}$ In accord with this observation, the level of CPP32 protein in HC-11 mouse mammary epithelial cells was nearly undetectable. CR-1 upregulated CPP32 expression in confluent growth-factor deprived $\mathrm{HC}-11$ cells. This effect might contribute to the apoptotic process observed in confluent $\mathrm{HC}-11$ cell cultures. Since $\beta$-catenin is found in the adherens junctions of epithelial cells with $\mathrm{E}$-cadherin and is involved in regulating homotypic cell-cell adhesion, then degradation of $\beta$-catenin would potentially lead to a loss of cell contact. ${ }^{21,36}$ This effect may be important not only with respect to the initiation of apoptosis but also in regulating the ability of CR-1 to stimulate branching morphogenesis. ${ }^{10,11,21}$ Analogously, it has been recently shown that hepatocyte growth factor, which also induces branching morphogenesis of mouse and human mammary epithelial cells, can promote apoptosis by increasing caspase-3 activity. ${ }^{37}$

Another important factor to be considered is that CR-1 is facilitating apoptosis in confluent cultures of $\mathrm{HC}-11$ cells that have been depleted of two crucial survival factors, EGF and insulin. ${ }^{38}$ This correlates with a previous report demonstrating that $\mathrm{HC}-11$ cells in high density cultures have a reduced contact with a solid substrate, which is known to facilitate the onset of apoptosis through a process known as anoikis. ${ }^{38,39}$ Under these culture conditions, the levels of the p21 bax protein increase in mammary epithelial cells. ${ }^{38,40,41}$ High levels of p21 bax protein are normally observed in confluent $\mathrm{HC}-11$ cells. ${ }^{38}$ However, high cell density and therefore, high levels of p21 bax expression are not entirely sufficient to induce apoptosis. ${ }^{38}$ Addition of pro-apoptotic cytokines such as CR-1 may be equally important at an early stage in this system in triggering apoptosis. Since $\mathrm{HC}-11$ cells lack wild type $\mathrm{p} 53,{ }^{42} \mathrm{CR}-1$ is probably inducing apoptosis in this system through a p53-independent pathway. In contrast to these results, Niemeyer et al recently found that in CID-9 mouse mammary epithelial cells that were transfected with a mouse $\mathrm{Cr}-1$ expression vector, growth was modestly stimulated and apoptosis under serum-restricted conditions was reduced by twofold. ${ }^{12}$ However, since CID-9 cells were assessed for apoptosis under sparse culture conditions in medium containing serum and insulin and since no indication was presented as to the amount of mouse $\mathrm{Cr}-1$ protein that was secreted by these cells, it is difficult to compare this data with the results obtained on confluent $\mathrm{HC}-11$ cells that have been treated with purified recombinant human CR-1 in the absence of EGF or insulin. In addition, in $\mathrm{HC}-11$ cells, apoptosis is more pronounced in serum-restricted confluent cultures than in sparse or subconfluent cultures. ${ }^{38}$

Finally, CR-1 expression is elevated in a majority of mouse and human mammary tumors relative to noninvolved mammary epithelium. ${ }^{7,17,18,20}$ In breast hyperplasia, ductal carcinoma in situ (DCIS) and invasive carcinomas, the degree of apoptosis has been shown to be correlated with increased malignancy. ${ }^{3,43}$ It is therefore conceivable that CR-1 may be one factor that is contributing to the elevated apoptotic index in these lesions since CR-1 expression can first be detected in hyperplasias in different transgenic mice that eventually develop mammary tumors and in human DCIS. ${ }^{5,10,20,51}$ Overexpression of $\mathrm{Cr}-1$ in NOG-8 or CID-9 mouse mammary epithelial cells in vitro leads to transformation in vitro as evidenced by an enhanced anchorage-dependent growth in the absence or presence of serum, a loss of contact inhibition of growth and an increase in anchorage-independent cell growth. ${ }^{10,12,44}$ However, both NOG-8 and COMMA-1D mouse mammary epithelial cells that were overexpressing either human $\mathrm{CR}-1$ or mouse $\mathrm{Cr}-1$, respectively, were unable to form tumors in either nude mice or Balb/c mice, respectively. ${ }^{12,44}$ The finding that $\mathrm{CR}-1$ is involved in both inducing apoptosis and promoting the early stages of transformation is analogous to the effects that are produced by another EGF-related growth factor, heregulin. Heregulin is primarily expressed in the stroma of the midpregnant mouse mammary gland and has also been shown to induce apoptosis in mouse and human mammary epithelial cells and to enhance the early stages of tumor formation in the mouse mammary gland. ${ }^{45-49}$ In conclusion, cell proliferation and apoptosis in mammary epithelial cells reflect a complex balance between two processes that are controlled by systemic mammotrophic and lactogenic hormones and locally-derived growth factors. A better understanding of these processes will help to elucidate the significant role that growth factors play in regulating normal mammary gland physiology and neoplasia.

\section{Materials and Methods}

\section{Cell culture}

HC-11 mouse mammary epithelial cells were grown until confluence in RPMI 1640 medium supplemented with $10 \%$ fetal bovine serum (FBS), $10 \mathrm{ng} / \mathrm{ml} \mathrm{EGF}$, and $5 \mu \mathrm{g} / \mathrm{ml}$ insulin (GM). Confluent HC-11 cells were kept in GM medium for $48 \mathrm{~h}$ and then treated with CR-1 in RPMI 1640 medium containing $3 \%$ FBS. Treatment of HC-11 cells with $20 \mu \mathrm{M}$ caspase inhibitor, ZVAD.FMK (ZVAD); $20 \mu \mathrm{M}$ of the general caspase inhibitor BMD.FMK (BOC) or with $20 \mu \mathrm{M}$ negative control, ZFAFK.FMK, was initiated $1 \mathrm{~h}$ prior to the addition of CR-1. All caspase and control inhibitors were purchased from Enzyme Systems Products; Dublin, CA, USA. No cellular toxicity was observed with the concentrations of inhibitors that were used in the experiments.

Cell proliferation was assessed in non-confluent $\mathrm{HC}-11$ cell cultures using WST-1 reagent (Boehringer-Mannheim, Indianapolis, IN, USA). Briefly, $\mathrm{HC}-11$ cells were plated in 96 -well plates at $2 \times 10^{3}$ 
cells per well in $3 \%$ FBS containing medium. The cells were incubated with CR-1 for 48 and $72 \mathrm{~h}$. WST-1 was added during the last $4 \mathrm{~h}$ of the incubation period as recommended by the manufacturer. The color developed was quantified using an ELISA reader and read at $450 \mathrm{~nm}$.

\section{Detection of apoptotic cells}

Bis-benzimide staining Morphological changes in the nuclear condensation of chromatin of cells undergoing apoptosis were assessed by staining with the DNA-binding fluorochrome bisbenzimide (Hoechst 33258; Sigma) as described elsewhere. ${ }^{50}$ In brief, $\mathrm{HC}-11$ cells were plated in polysterene chamber slides (LabTek) at $5 \times 10^{4}$ until confluent. The cells were then kept for $48 \mathrm{~h}$ in GM medium and then treated with or without CR-1 at different concentrations in the presence of $3 \%$ FBS for different times. After treatment, the cells were washed twice with PBS and incubated with $3.5 \%$ paraformaldehyde in PBS for 20 min at room temperature. After fixation, the cells were washed twice with PBS and stained with bisbenzimide $(16 \mu \mathrm{g} / \mathrm{ml})$ in PBS. Following $15 \mathrm{~min}$ of incubation at room temperature, the cells were washed twice with PBS and the average number of nuclei per field was scored for the incidence of apoptotic chromatin under a fluorescence microscope. Cells with three or more condensed chromatin fragments were considered apoptotic.

TUNEL assay $\mathrm{HC}-11$ cells were plated in polysterene chamber slides (LabTek) at $5 \times 10^{4}$ until confluence. The cells were kept in GM medium for $48 \mathrm{~h}$ and then treated with or without CR-1 (100 or $200 \mathrm{ng} / \mathrm{ml})$ or EGF $(100 \mathrm{ng} / \mathrm{ml})$ in the presence of $3 \%$ FBS for different times. After treatment, the cells were washed twice with PBS and incubated with 3.5\% paraformaldehyde in PBS for 20 min at room temperature. DNA fragmentation in apoptotic cells was determined by measuring terminal deoxynucleotidyltransferase activity by the terminal de-oxynucleotidyltransferase-mediated dUTP-biotin nick end labeling, (TUNEL) assay (BoehringerMannheim, Indianapolis, IN, USA). TUNEL-positive cells were examined using a fluorescence microscope.

DNA fragmentation cell death ELISA $\mathrm{HC}-11$ cells were plated in 48-well plates at $1 \times 10^{4}$ cells per well and grown until confluence. The cells were kept in GM medium for $48 \mathrm{~h}$ and then treated with or without CR-1 $(100 \mathrm{ng} / \mathrm{ml})$ in the presence or absence of caspase inhibitors at the indicated concentrations in RPMI 1640 medium containing $3 \%$ FBS for $36 \mathrm{~h}$. After incubation, cytoplasmic nucleosomal DNA fragments were assessed using an apoptotic cell death ELISA (Boehringer Mannheim) with anti-histone and antiDNA antibodies, as previously described to assess DNA fragmentation. ${ }^{50}$ The color developed was quantified using an ELISA reader and read at $405 \mathrm{~nm}$.

\section{Western blot analysis}

Cells were lysed and homogeneized in a buffer containing $20 \mathrm{mM}$ Tris$\mathrm{HCl}, \mathrm{pH} 7.5,150 \mathrm{mM} \mathrm{NaCl}, 1 \%$ Nonidet P-40, 0.5\% deoxycholate, $5 \mathrm{mM} \mathrm{MgCl} 2,2 \mu \mathrm{g} / \mathrm{ml}$ aprotinin, $2 \mu \mathrm{g} / \mathrm{ml}$ leupeptin, $1 \mathrm{mM}$ phenylmethylsulfonyl fluoride, $1 \mathrm{mM}$ orthovanadate, and $20 \mathrm{mM}$ sodium fluoride. After clarification, $100 \mu \mathrm{g} / \mathrm{sample}$ of the protein lysates were separated by SDS-PAGE, transferred to nitrocellulose and blocked with $4 \%$ dry milk in $20 \mathrm{mM}$ Tris-buffered saline with $0.05 \%$ Tween 20 . The blots were incubated with either a 1:1000 dilution of a rabbit antiPARP antibody (Biomol, Pennsylvania, USA), a 1:1000 dilution of both mouse monoclonal anti- $\beta$-catenin and monoclonal anti- $\alpha$-catenin antibodies from Transduction Laboratories (Kentucky, USA); a 1:400 dilution of a rabbit anti-CPP32 antibody (Upstate Biotechnology Inc.,

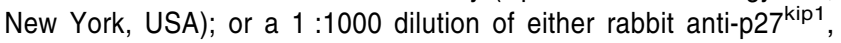
rabbit anti-bcl-x or rabbit anti-bax antibodies from Santa Cruz Biotechnology Inc. (California). The bound rabbit or mouse antibodies were detected using a 1:3500 dilution of either goat-anti-rabbit or goat-anti-mouse IgG conjugated to horseradish peroxidase (Amersham Corp.). Quantitation of bands was measured by densitometric analysis.

\section{Acknowledgements}

AD Ebert was supported by DFG grant Eb 152/42.

\section{References}

1. Imagawa W, Dandyopadhyay GK and Nandi S (1990) Regulation of mammary epithelial cell growth in mice and rats. Endocrine Rev. 11: 494-523

2. McCloskey DE, Armstrong DK, Jackisch and Davidson NE (1996) Programmed cell death in human breast cancer cells. Recent Progress in Hormones Research 51: 493-508

3. Hahm HA and Davidson NE (1998) Apoptosis in the mammary gland and breast cancer. Endocrine-Related Cancer 5: 199-211

4. Donjacour AA and Cunha GR (1991) Stromal regulation of epithelial function. In: Regulatory Mechanisms in Breast Cancer, Lippman M and Dickson RB, (eds). Boston: Kluwer Academic Press pp. 335-364

5. Normanno Nand Ciardiello F (1997) EGF-related peptides in the pathophysioloy of the mammary gland. J. Mammary Gland Biol. Neoplasia 2: 143-151

6. Vonderhaar BK (1988) Regulation of development of the mammary gland by hormones and growth factors. In: Breast Cancer: cellular and molecular biology, LippmanMandDicksonRB,(eds). Boston:KluwerAcademicPresspp.251-266

7. Salomon DS, Bianco C and De Santis M (1999) Cripto: a novel epidermal growth factor (EGF)-related peptide in mammary gland development and neoplasia. BioEssays 21: $61-70$

8. Smith GH, Sharp R, Kordon EC, Jhappan C and Merlino G (1995) Transforming growth factor- $\alpha$ promotes mammary tumorigenesis through selective survival and growth of secretory epithelial cells. Am. J. Pathol. 147: 1081-1096

9. De Santis ML, Kannan S, Smith GH, Seno M, Bianco C, Kim N, Martinez-Lacacil, Wallace-Jones B and Salomon DS (1997) Cripto-1 inhibits $\beta$-casein expression in mammary epithelial cells through a $21^{\text {ras }}$ - and phosphatidylinositol-3-kinasedependent pathway. Cell Growth Diff. 8: 1257-1266

10. KenneyNJ,SmithGH,JohnsonM,LohmeyerM,GullickWJ,SalomonDSandDickson RB (1997) Cripto-1 activity in the mouse mammary gland: a novel candidate that specificallyaffectsductalprogenitorcells. Pathogenesis 1:57-71

11. Seno M, De Santis ML, Kannan S, Bianco C, Tada H, Kim N, Kosaka M, Gullick WJ, Yamada H and Salomon DS (1998) Purification and characterization of a recombinant human cripto-1 protein. Growth Factors 15: 215-229

12. Niemeyer CC, Persico MG and Adamson ED (1998) Cripto: roles in mammary cell growth, survival, differentiation and transformation. Cell Death Differ. 5: $440-449$

13. Kannan S, De Santis ML, Lohmeyer M, Riese DJ II, Smith GH, Hynes N, Seno M, Brandt R, Bianco C, Persico G, Kenney N, Normanno N, Martinez-Lacaci I, Ciardiello F, Stern DF, Gullick WJ and Salomon DS (1997) Cripto enhances the tyrosine of Shc and activates mitogen-activated protein kinase (MAPK) in mammary epithelial cells. J. Biol. Chem. 272: 3330-3335

14. Bianco C, Kannan S, De Santis M, Seno M, Tang CK, Martinez-Lacaci I, Kim N, Wallace-Jones B, Lippman ME, Ebert A, Wechselberger C and Salomon DS (1999) Cripto-1 indirectly stimulates the tyrosine phosphorylation of erb B-4 through a novel receptor. J. Biol. Chem. 274: 8624-8629

15. Kenney N, Huang R-P, Johnson GR, Wu J-X, Okamura D, Matheny W, KordonE, Gullick WJ, Plowman GR, Smith GH, Salomon DS and Adamson ED (1995) Detection and location of amphiregulin and cripto-1 in the developing mouse mammary gland. Mol. Reprod. Develop. 41: 277-286

16. Herrington EE, Ram TG, Salomon DS, Johnson GR, Gullick WJ, Kenney NJ and Hosick HJ (1997) Expression of epidermal growth factor-related proteins in the aged adult mouse mammary gland and their relationship to tumorigenesis. J. Cell. Physiol. 170: $47-56$ 
17. Normanno N, Qi C-F, Gullick WJ, Persico G, Yarden Y, Wen D, Plowman G Kenney N, Johnson G, Kim N, Brandt R, Martinez-Lacaci I, Dickson RB and Salomon DS (1993) Expression of amphiregulin, cripto-1, and heregulin in human breast cancer cells. Int. J. Oncol. 2: 903-911

18. Qi CF, Liscia DS, Merlo G, Normanno N, Johnson G, Gullick WJ, Ciardiello F, Brandt R, Kim N, Kenney N and Salomon DS (1994) Expression of transforming growth factor $\alpha$, amphiregulin and cripto- 1 in human breast carcinomas. British J. Cancer 69: 903-910

19. Kenney NJ, Smith GH, Maroulakou IG, Green JH, Muller WJ, Callahan R, Salomon DS and Dickson RB (1996) Detection of amphiregulin and cripto-1 in mammary tumors from transgenic mice. Mol. Carcinogen. 15: 44-56

20. Panico L, D'Antonio A, Salvatore G, Mezza E, Tortora G, De Laurentiis M, De Placido S, Giordano T, Merino M, Salomon DS, Gullick WJ, Pettinato G, Schnitt SJ, Bianco AR and Ciardiello F (1996) Differential immunohistochemical detection of transforming growth factor $\alpha$, amphiregulin and cripto in human normal and malignant breast tissues. Int. J. Cancer 65: 51-56

21. Brancolini C, Lazarevic D, Rodriguez and Schneider C (1997) Dismantling cellcell contacts during apoptosis is coupled to a caspase-dependent proteolytic cleavage of $\beta$-catenin. J. Cell Biol. 139: 759-771

22. Lincz LF (1998) Deciphering the apoptotic pathway: All roads lead to death Immunol. Cell Biol. 76: 1-19

23. Thornberry NA and Lazebnik Y (1998) Caspases: enemies within. Science 281 $1312-1316$

24. Adams JM and Cory S (1998) The Bcl-2 protein family: arbiters of cell survival. Science 281: 1322-1326

25. Fraser A and Evan G (1996) A license to kill. Cell 85: 781-784

26. Brandt R, Normanno N, Gullick WJ, Lin J-H, Harkins R, Schneider D, Jones B-W Ciardiello F, Persico MG, Armenante F, Kim N and Salomon DS (1994) Identification and biological characterization of an epidermal growth factorrelated protein: Cripto-1. J. Biol. Chem. 269: 17320-17328

27. Danielson KG, Oborn CJ, Durban EM, Butel JS and Medina D (1984) Epithelial mouse mammary cell line exhibiting normal morphogenesis in vivo and functional differentiation in vitro. Proc. Natl. Acad. Sci. USA 81: 3756-3760

28. Merlo GR, Graus-Porta D, Cella N, Marte BM, Taverna D and Hynes NE (1996) Growth, differentiation and survival of $\mathrm{HC} 11$ mammary epithelial cells: diverse effects of receptor tyrosine kinase-activating peptide growth factors. Eur. J. Cell Biol. 70: $97-105$

29. Saltzman A, Munro R, Searfoss G, Franks C, Jaye M and Ivaschenko Y (1998) Transforming growth factor- $\beta$-mediated apoptosis in the Ramos B-lymphoma cell line is accompanied by caspase activation and bcl- $\mathrm{x}_{\mathrm{L}}$ downregulation. Exp. Cell Res. 242: 244-254

30. Lazebnik YA, Kaufmann SH, Desnoyers S, Poirier GG and Earnshaw WC (1994) Cleavage of poly(ADP-ribose) polymerase by a proteinase with properties like ICE. Nature 371: $346-347$

31. Rodeck U, Jost M, DuHadaway J, Kari C, Jensen PJ, Risse and Ewert DL (1997) Regulation of $\mathrm{Bcl}-\mathrm{X}_{\mathrm{L}}$ expression in human keratinocytes by cell-substratum adhesion and the epidermal growth factor receptor. Proc. Natl. Acad. Sci. USA 94: $5067-5072$

32. Han EK-H, Begemann M, Sgambato A, Soh J-W, Doki Y, Xing W-QX, Liu W and Weinstein B (1996) Increased expression of cyclin D1 in a murine mammary epithelial cell line induces p $27^{\text {kip } 1}$, inhibits growth, and enhances apoptosis. Cell Growth and Differ. 7: 699-710

33. Strange R, Friis RR, Bernis LT and Geske FJ (1995) Programmed cell death during mammary gland involution. Methods in Cell Biol. 46: 355-368

34. Clem RJ, Cheng E H-Y, Karp CL, Kirsch DG, Ueno K, Takahashi A, Kastan MB, Griffin DE, Earnshaw WC, Veliuona MA and Hardwick JM (1998) Modulation of cell death by Bcl- $x_{\mathrm{L}}$ through caspase interaction. Proc. Natl. Acad. Sci. USA 95 $554-559$
35. Zapata JM, Krajewska M, Krajewski S, Huang R-P, Takayama S, Wang H-G, Adamson E and Reed JC (1998) Expression of multiple apoptosis-regulatory genes in human breast cancer cell lines and primary tumors. Breast Cancer Research and Treatment 47: 129-140

36. Klymkowsky MW and Parr B (1995) The body language of cells: the intimate connection between cells adhesion and behavior. Cell 83: $5-8$

37. Arakaki N, Kazi JA, Kazihara T, Ohnishi T and Daikuhara Y (1998) Hepatocyte growth factor/scatter factor activates the apoptosis signaling pathway by increasing caspase-3 activity in sarcoma 180 cells. Biochem. Biophys. Res. Comm. 245: 211-215

38. Merlo GR, Cella N and Hynes NE (1997) Apoptosis is accompanied by changes in Bcl-2 and Bax expression, induced by loss of attachment, and inhibited by specific extracellular matrix proteins in mammary epithelial cells. Cell Growth and Differ. 8: 251-260

39. Frisch SM and Francis H (1994) Disruption of epithelial cell-matrix interactions induces apoptosis. J. Cell Biol. 124: 619-626

40. Heermeir K, Benedict M, Minglin L, Furth P, Nuñez G and Hennighausen (1997) Bax and $b c l-x_{S}$ are induced at the onset of apoptosis in involuting mammary epithelial cells. Mechanisms of Development 56: 197-207

41. Li M, Liu X, Robinson G, Bar-Peled U, Wagner K-U, Young WS, Hennighausen L and Furth PA (1997) Mammary-derived signals activate programmed cell death during the first stage of mammary gland involution. Proc. Natl. Acad. Sci. USA 94: 3425-3430

42. Merlo GR, Basolo F, Fiore L, Duboc L and Hynes NE (1995) p-53 dependent and p-53 independent activation of apoptosis in mammary epithelial cells reveals a survival function of EGF and insulin. J. Cell Biol. 128: 1185-1196

43. Soini Y, Paako P and Lehto V-P (1998) Histopathological evaluation of apoptosis in cancer. Am. J. Pathol. 153: 1041-1053

44. Ciardiello F, Dono R, Kim N, Persico MG and Salomon DS (1991) Expression of cripto, a novel gene of the epidermal growth factor gene family, leads to in vitro transformation of a normal mouse mammary epithelial cell line. Cancer Res. 51: 1051-1054

45. Yang Y, Spitzer E, Meyer D, Sachs M, Niemann C, Hartmann G, Weidner KM, Birchmeier C and Birchmeier W (1995) Sequential requirement of hepatocyte growth factor and neuregulin in the morphogenesis and differentation of the mammary gland. J. Cell Biol. 131: 215-226

46. Krane IM and Leder P(1996) NDF/heregulin induces persistence of terminal end buds and adenocarcinomas in the mammary glands of transgenic mice. Oncogene 12: 1781-1788

47. Daly JM, Jannot CB, Beerli RR, Graus-Porta D, Maurer FG and Hynes NE (1997) Neu differentiation factor induces erbB2 downregulation and apoptosis of erbB2overexpressing breast tumor cells. Cancer Res. 57: 3804-3811

48. Grimm SM Weinstein EJ, Krane IM and Leder $P$ (1998) Neu differentiation factor (NDF), a dominant oncogene, causes apoptosis in vitro and in vivo. J Exp. Med. 188: $1535-1539$

49. Weinstein EJ, Grimm S and Leder P (1998) The oncogene heregulin induces apoptosis in breast epithelial cells and tumors. Oncogene 17: 2107-2113

50. Nass SJ, Li M, Amundadottir LT, Furth PA and Dickson RB (1996) Role for bcl-xL in the regulation of apoptosis by EGF and TGF $\beta 1$ in c-myc overexpressing mammary epithelial cells. Biochem. Biophys. Res. Comm. 227: 248-256

51. Niemeyer CC, Spencer-Dene B, Wu J-X and Adamson ED (1999) Preneoplastic mammary tumor markers: cripto and amphiregulin are overexpressed in hyperplastic stages of tumor progression in transgenic mice. Int. J. Cancer 81: 588-591 